\title{
The Social Crises, Political Conflicts and Cultural Contradictions of "Nixonland:" Tracing Constitutional Crisis in the USA from Nixon to Trump*
}

\author{
Timothy W. Luke
}

Many developments, like greater domestic turmoil, economic dislocation, social immobility, and political gridlock, suggest "the public" and "the private" are different domains with the US than they were decades ago in 1969 when President Nixon entered office. The constitutional state, as a theory and set of practices in the USA in the Nixon era was put under tremendous strains, and it seems clear that those pressures fractured it. After Vietnam, stagflation, Watergate, and the transitional Ford Administration, has it ever been the same? The Reagan-Bush assault on the New Deal and Great Society as well as the essentially permanent mobilization for war in the Middle East since 1991 all should force us to conduct a radical check-up of the body politic, and ask if The Constitution is, in fact, the nation's benchmark for foundational law. This paper argues that major political and cultural shifts within the USA, as it has faced these new challenges since the 1970s that have been both domestic and global in nature, suggest that its 1787 Constitution no longer organically underpins the nation's dominant modes of the governance, principles of sovereignty, or notions of political legitimacy, as they have been expressed since 1969 or 2001 in the larger New World Order organized in Washington, D.C.

\section{Introduction}

On November 9, 2016, millions of Americans were jolted by the astounding victory of Donald J. Trump over Hilary Clinton in a very close presidential election. Many asked what just happened, how could this be, where did this come from? This analysis suggests it began in unsettled battles still being waged from decades ago. On January 20, 1969, a member of the age cohort many regard as "The Greatest Generation," Richard M. Nixon took the oath of office as President of the United States.

Five years and 201 days later on August 9, 1974, he resigned to avoid a Senate trial on articles of impeachment from the House of Representatives after committing a series of acts that Congress 
and many American citizens regarded as not faithfully executing his duties as President of the United States, namely, to "preserve, protect, and defend the Constitution of the United States." In the five decades since 1969, however, it is apparent that Nixon ironically fulfilled the prophetic observation he made in the second sentence of his First Inaugural Address: "Each moment in history is a fleeting time, precious and unique. But some stand out as moments of beginning, in which courses are set that shape decades or centuries" (Nixon, 1969).

During his fleeting moment in history, Nixon's years in the White House steered America down a different course, which has tested its body politic over the decades since 1968. Indeed, the divisive politics of his electoral campaign and presidency enabled the emergence of today's highly polarized, truly inegalitarian, and sullenly nationalist times in "The Trump Zone" (Luke, 2016) by inventing the dark political imaginaries of "Nixonland."

Given the open hostilities and boiling anxieties, which have wracked Nixonland since 1968, the USA has gradually failed as a superpower, after dreaming during brighter days of opening "A New Frontier" and "The Great Society" for all Americans in the Kennedy-Johnson era. The USA's largely GOP presidential administrations since 1968, despite brief respites under Carter, Clinton, and Obama, have failed, economically and politically, to cope with the tough challenges placed before three generations of Americans. After the relative triumphs of the New Deal and World War II, the "Trente Glorieuses" of general growth and prosperity after 1945 are barely remembered by many Americans, but that memory is charged indistinctly with "greatness." Back in everyday life, the darker gloom of the deadlocked armistice after war in Korea, racial conflicts still simmering from the civil rights movement, the Vietnam debacle, senseless Cold War struggles, the collapse of the USSR, the 9/11 attacks, endless wars in Syria, Iraq, and Afghanistan, and the economic dislocation of many small and great recessions coldly shadow most Americans, especially as they "shelter in place" during the global COVID-19 pandemic that burst forth during the 2020 lunar new year.

The allegorical notion of "Nixonland," then, is not just about one Republican president. Rather it tracks, as Perlstein (2001) argues, a turbulent on-going reconfiguration of social/ political/cultural imaginaries animating America's body politic as it continues to grapple with the still potent knock-on effects of tremendous turmoil kicked up since the 1960s. These cultural conflicts, economic divisions, and social forces are greater than those that are usually reduced to today's alt-right "populism," but such smoldering conflicts are essential elements for the crisisridden workings of Donald J. Trump's electoral campaigns and presidential administration.

Sometimes envisioned as suburbia's "Silent Majority," other times regarded as "clingers to guns and God," and at other moments dismissed as "the Deplorables," these social forces are very much in play today as a base of the Trump administration. As that large "majority minority" of white, older, once moderate bloc of "the American people," they have been hounded continuously since the Carter years in a permanent political campaign to control the White House by the shape-shifting coalitions of would-be ruling elites. As the Cold War-era bipartisan establishment cracked during the lost wars in Southeast Asia (1965-1975) and largely fragmented in the lost wars in Southwest Asia (1990-2020), despite "winning the Cold War" against the Soviet Union during 1989-1991, a relative know-nothing petty billionaire like Trump could fill these civic voids by promising to "Make America Great Again." Such seismic social shifts must be considered to comprehend fully the USA's current degraded conditions from their origins in Nixonland. It is not the whole story, but the continuing constitutional crises Nixon's administration triggered are real. From first promising "peace with honor" in Vietnam, and starting a "war of choice" with the 
1970 Cambodian invasion, launching the Watergate affair to crush his personal enemies, agreeing to nuclear parity over superiority to gain détente with Moscow, declaring a War on Drugs to police the nation's cities and underclass, and then declaring admiration for Communist China to geopolitically contain Moscow with Beijing, the conditions of "this is not normal" in the White House during 2020 become slightly more sensible by rethinking key events in Nixonland since 1970.

To map these troubling qualities, this study unfolds in six parts. After scanning the scenes on this stage in Section I, Section II probes the contradictions in the USA's constitutional order that many have seen leading "in the future" to "a constitutional crisis." Section III calls it like it is: this future opened decades ago, and that "constitutional" crisis already happened. Today, public affairs openly are shaped now by the workings of a new "Crisis Constitution." Section IV asks plainly "what Constitution" are we worried about--the one frozen in solemn print from 1787 or the one that has been evolving in moments of sustained panics and manic chaos since 1898? Section V maps the erosion of the 1787 Constitution in the crises reconstructing the USA from 1899 to 2019. And, Section VI explores how the spirit of democracy is being eroded under this Crisis Constitution and the defense of America's empire of bases.

\section{The Birth of a New Nation: Nixonland}

Ultimately, the sagas of Nixonland are about how the American electorate -- "the white majority" or "non-white minority" "the affluent society" or "the other America" -- whether from the "red" or "blue" states, has come to see the USA trapped "in a pitched battle between the forces of darkness and the forces of light" (Perlstein, 2009: xii) since 1968. The relatively moderate bi-partisan electorate that has accepted Harry S Truman, Dwight D. Eisenhower, and John Fitzgerald Kennedy as presidents split apart during the years after JFK's assassination. Yet, one must recall how sharply contested Kennedy's vision of America was in 1961. In his only inaugural address, he made a provocative claim that had never was made good by "the Greatest Generation" of which he spoke: "the torch has been passed to a new generation of Americans -- born in this century, tempered by war, disciplined by a hard and bitter peace, proud of our ancient heritage -- and unwilling to witness or permit the slow undoing of those human rights to which this Nation has always been committed, and to which we are committed today at home and around the world" (Kennedy, 1961).

How disciplined by a bitter peace, how unwilling to permit the undoing of human rights anywhere, and how committed to waging these struggles at home and abroad were Americans remain very contestable claims. By 1964, the electorate was divided deeply over which figure, program or party could represent its future best. Most citizens brushed off JFK's heroic declarations. Instead, many voters in both parties took to heart Senator Barry Goldwater's angry call to the 1964 Republican National Convention, asserting "that extremism in the defense of liberty is not vice," and "that moderation in the pursuit of justice is no virtue" (Goldwater, 1964).

Whether it has been for Goldwater, Nixon, Reagan, a Bush, McCain or Trump, on the one hand, or Johnson, McGovern, Carter, Gore, Obama or a Clinton, on the other hand, "the voter" since 1964 increasingly has pulled the lever at the polls for her or his chosen candidate as ticketsplitting independents. Such voting trends by independents, who have much weaker or no ties to the national parties and Cold War-era bipartisan institutions that emerged after 1945 has grown stronger, in turn, for over five decades, since many voters believe that to do otherwise "seemed to 
court civilizational chaos" (Perlstein, 2009: xiii). For over five decades, thanks to the institutional collapse of the Democratic party after its disastrous 1968 campaigns, and the GOP's mass media merchandising of President M. Nixon and Vice-President Spiro T. Agnew as slickly packaged upright moral alternatives to "the counter-culture" of the civil rights, anti-war, women's rights, and environmental movement policies tolerated by Hubert H. Humphrey in the Democratic Party, Nixon's reengineering of national campaign finance laws did change parties and elections.

Instead of organized groups of permanent partisans devoted to disciplined political debate, the national political parties morphed into endless fund-raisers, public and private monies supported televisual modes of campaigning rooted in mass consumer marketing of people as products in Nixonland. This cynical shift essentially also allowed the national political parties to declare themselves "independent" of their voters and elections by continuously soliciting campaign and PAC funds from anyone who would contribute at any time, energy, and money to them. The electorate's hope to avoid disruptive cultural, economic, political, and social crises largely came to naught after Vice-President Agnew and President Nixon respectively resigned from their elected offices under thick clouds of corruption, chaos, and criminality on October 10, 1973 and August 9, 1974.

Instead of Camelot, during Nixon's "precious and unique moments of beginning" still lit by JFK's "torch that passed" to "the Greatest Generation," America witnessed the emergence of Nixonland. Beset by Watergate, Billygate, Iran/Contragate, the Savings and Loan crisis, Whitewater, Monicagate, 9/11, Iraq's “missing" weapons of mass destruction, Abu Ghraib, the VA Hospital scandals, Hilary Clinton's e-mail fiascos, Benghazi, and the Obamacare feud along with so many other economic crashes, institutional failures, and cultural conflicts since 1968, many pundits sincerely opined "America was ready for a real change" in 2016. And, in a way, America got what it supposedly wanted.

Since January 2017, the USA has been led in a fashion by the Trump White House, which in the assessment of a former presidential Chief-of-State, General John F. Kelly, is occupied by "an idiot. It is pointless to try to convince him of anything. He's gone off the rails. We are in crazy town" (Woodward, 2018: 286). To see "the Trump Zone" developing out of "Nixonland" five decades later can be confirmed by noting other parallels. As statesmen, both Nixon and Trump campaigned under heavy clouds of dark suspicion: Nixon tainted by prior electoral losses plus his angry dark disposition, and Trump by his buffoonish "reality TV star" status with no prior service in political office. Like Trump in 2016, Nixon came into office under doubt as a minority president. Nixon, due to the third American Independent Party votes taken by George Wallace and Curtis LeMay, and Trump also due to a lower popular national vote but higher Electoral College count. Both presidents had GOP majorities in the House and Senate their first two years in office. Yet, after tense months of frantic activity at home and abroad to legitimize his mandate, Trump in 2018, like Nixon in 1970, suffered considerable losses in the following mid-term elections, losing leverage to work with some of his own party and with the revitalized Democratic opposition. In turn, both men immediately resented their electoral setbacks, seeing them as vicious efforts to discredit them personally, if not destroy them individually. These perceived and real attacks emboldened both presidents to mercilessly attack any perceived and real enemies to crush them first, even if it meant corrupting the daily operations of the White House and federal government.

Nixon, however, first effectively forged "a public language that promised mastery of the strange new angers, anxieties, and resentments wracking the nation in the 1960s" (Perlstein, 2009: xii), which became the new lingua franca of electoral and legislative life of the coming 
decades as the never-ending stories of the 1960s continued in civic life. Thanks to Steve Bannon and Kelly Anne Conway, Trump refined this crude political vulgate as a "reality TV star" and wannabe politico to effectively channel many of Americans' fears about the post-9/11 world with its fruitless wars, economic dislocations, cultural apprehensions, and racial reactions into what Nixon's campaigns also reprocessed as "voting issues" (Perlstein, 2009: xii). The Trump team pushed back against the post-1991 New World Order of globalization, Silicon Valley innovation, multiculturalism, and establishment elitism that "the Clintons" allegedly had helped construct. This culture warfare was not unlike Nixon's sad desire to eclipse the telegenic glory of JFK's and Jackie's Camelot years after his humiliating loss in 1960.

Certainly, there are other factors at work in the current constitutional convulsions shrouded by the endless carnival side-show provided by Donald J. Trump's election as President of the United States on November 9, 2016. The known unknown roles, as the Mueller Report detailed, played by various foreign intelligence operatives, backroom lobbying in Ukraine, and questionable real estate deals at home and abroad helped to leverage the Trump organization's success with endless unpaid campaign publicity on the nightly news. In distorting public debate, the information warfare conducted by the Russian Federation against the Democratic Party, the Clinton campaign, and social media platforms in the USA during 2016 was only the tip of the iceberg. None of this was "normal," but neither were the paranoid "black bag" and "plumber" operations directed from the White House at the core of Watergate. These extraordinary 2016 events, along with many other scandals, which were only partially uncovered in the 2018-2019 House investigation, of the manipulative Ukrainian arms deal fiasco behind the two articles of Trump's impeachment in the House during 2019 clearly also are "not normal."

\section{A. The Context of Current Chaos}

Trump's strange desultory efforts to gain national attention as a political contender began in the 1990s, when he made more than one quixotic self-guided foray into partisan political candidacy with other mass media phenomena, like Jesse Ventura, Arnold Schwarzenegger and Sarah Palin, during the turbulent years following Y2K. Ordinarily, such antics would have been dismissed, like Pat Paulson's repeated efforts to run for president from TV Sit-Com Land from the 1960s to 1990s as comedic. After the devastation of the Great Recession and the election of Barack Hussein Obama as President in 2008 and 2012, however, the electorate's mood had darkened. In turn, Donald J. Trump became a real contender to preside over the affairs of Nixonland.

In retrospect, Trump's erratic extremism, however, shaped his agenda to "Make America Great Again" at least since his attention-grabbing adherence to "the birther" movement's intense antipathy to Barack Obama since his election to the U.S. Senate, and then President of the United States. Unwilling to accept an African-American native from the state of Hawai'i, devotees of birtherism ran smear campaigns against Obama's Kenyan father, Peace Corps volunteer mother, and establishment liberal career. Trying to "out him" as an Alinsky radical, Islamic fundamentalist, academic Marxist, and, most importantly, a foreign alien whose allegedly bogus citizenship coupled with these other alleged suspect proclivities, birthers successfully focused some white voters' rage about a black president -- by transforming blatant racism into technicalities mired in immigration rules and residence laws -- in Trump's immoderate campaign to discredit Obama's legitimacy. How could such a person, especially an African-American, serve as an elected official in the nation's highest office? Once again one sees more of the bitter fruits of Barry Goldwater's 
challenge to the American consensus five decades earlier (Perlstein, 2001) in his attacks on LBJ, the 1964 Civil Rights Act, and the Great Society, driven by what he boasted was only well-intentioned "extremism in defense of liberty."

While feigning complete loyalty to the USA, Bannon and Trump manipulated such antiObama extremism tirelessly. Their goals were obvious: to discredit the man, his political party, the electoral system, and ultimately the US Constitution, because Obama is black, "played by the rules," beat an American POW hero from the Vietnam War, and then became President. Despite the aura of good racial relations in America that circulates through the media, the Trump vote registers a still white majority nation-state reacting to on-going aftershocks of the civil rights movement of the 1950s and 1960s. Likewise, for much of Black America despite Obama's 2008 and 2012 victories, many conditions are just as bad as ever, or worse. From President George W. Bush's bungled recovery efforts in New Orleans and the Gulf Coast after Hurricanes Katrina and Wilma, the collapse of Detroit as a functioning city, rising inner-city black-on-black violence tolerated by often white-dominated governments, and the personal security issues behind the Black Lives Matter movement, it is clear things are not improving in the perpetually underemployed, more jobless, less wealthy, and deeply disrespected black communities across the country. Despite Trump's promises in his 2017 inaugural address, "this American carnage" has not stopped "right here and stops right now” (Trump, 2017). Instead, Steve Bannon, Kellyanne Conway, and Stephen Miller leveraged the same mean resentment among the Silent Majority, which Wallace and Nixon easily tapped in 1968 about Black America, to give the Trump administration real momentum in 2016 and after.

\section{B. Crisis, Constitution, and Conflict}

There are other structural challenges in the twenty-first century, which is increasingly illiberal, undemocratic and misgoverned, to the liberal democratic model of government, even though they have been proliferating for 50 years after JFK's failed misadventures at home and abroad ended in 1963. In many ways, the elections of 1964, 1966, 1968, 1970, and 1972 anticipate those of 2010, 20012, 2014, 2016, and 2018. Recognizing how close "Nixonland" is to the "Trump Zone" takes on new importance for any study of sovereignty and freedom in America. Despite much talk, most institutional efforts to enhance American democracy -- more party primaries, voter campaign financing, primary clustering contests, etc. -- since 1968 have not led to much success. Constitutional theory, modes of sovereignty, and collective choice construction should come into sharper focus, because Citizens United, dark money in elections, more PACs with narrow agendas, and new social media are fragmenting the civic workings of America's political processes.

A rhetorical dimension always runs through constitutional theory, because any constitution should present a people's self-understanding of its political identity. Yet, the spirit of many traditional narratives has been lost in Nixonland for five decades. Political representation, order, and legitimacy must involve more than literary, mythic or theological projects spinning up thin visions of national identity every two years to tickle the people's self-conceptions of their community, nationality and/or unity (Hartz, 1955; Huntington, 1968; and, Lowi, 1979). After the organized deceptions of the Nixon White House to contain the counter-culture, degrade the Democratic Party, and juice up the national economy, even these basic rhetorical necessities are ignored. Instead, tales of misdeeds from the hounding of Martin Luther King, Jr. by the 
FBI to revolutionary delusions of the Weather Underground have spread the seeds of fugitive democracy, class conflict, inverted totalitarianism or imperial decline broadly since August 9, 1974. When Nixon flew away in Marine One from the White House South Lawn with a pardon in the offing and many other long national nightmares were not ending, they were waiting to begin. Here, then are a few spans in the "invisible bridge" from Nixon to Reagan to Trump (Perlstein, 2015).

The Founders sought to enable "the People of the United States" to create a more perfect union in 1787. "The People," of course, were then a small powerful minority of the population: white, male, propertied, with trades or a competence. They were divided by economic interests, urban/rural divisions, sectional competition, foreign origin, and religious conviction. In an imperfect manner, and with considerable violence, this union of thirteen states launched their rough-and-tumble struggles to govern.

In unending battles over race, class, faith, gender, and region, this state struggles to establish some measures of justice, insure a bit of domestic tranquility, provide for the common defense, promote with difficulty the general welfare, and slowly secure some blessings of liberty for itself, always at the cost of other peoples, over 230 years of struggle. Nonetheless, the full scope of this posterity is still to be determined. Their document superseded the initial Articles of Confederation and Perpetual Union adopted during 1777 and ratified in 1781, and propounded new principles of political representation, while wrestling with an evolving self-understanding of "The People's" identity. Even then, its governance unfolded in highly contested conditions of rule from the initial factional fights between the Federalists and Anti-Federalists in the 1790s to those between "red states" and "blue states" today since the 1990s.

After campaigning to attain "peace with honor" in Vietnam during 1968, Nixon expanded the Vietnamese war by invading Cambodia, hit North Vietnam with sustained aerial bombing, and set the stage for South Vietnam's collapse, which became a frantic withdrawal in panic under President Ford in 1975. What has enabled the government operatives of Nixonland to continue pursuing such military interventions, and remain engaged in a permanent low-intensity war for 50 years? Since the McKinley administration, years of peace for America have been the exception, and war is the norm. A volatile blend of not-peace/not-war has spliced together pitched battles during openly declared "war time" with tense alerts during "peace time" from the SpanishAmerican War through today's Global War on Terror. This is not what the 1787 Constitution was designed to promote and protect.

\section{| II. Domestic Tranquility Lost, Common Defense Above All}

The prevailing view of the USA in 1991 was glowing: it had won the Cold War, which clicked into place during 1946-1947 around the world as the US/Soviet "special relationship" of 19411945 shattered. It had also successfully concluded "the Gulf War" against Iraq and liberated Kuwait from Baghdad's control after its backers in Moscow disappeared. For many, its everyday governance was effective, its constitutional order was solid, and its political culture generally tended toward democratic goals.

Still, a generation later, grim facts must be recalled. The Republic definitely has been at war since the turn of the twenty-first century in the wake of Islamic terrorist attack against the USS Cole on October 12, 2000 (during the very close George W. Bush versus Al Gore, Jr. presidential race) in Yemen's Aden Harbor by Al-Qaeda operatives. These Islamic terrorist offensives deepened 
on 9/11/2001. Tallies made under the Obama Administration revealed American military units were engaged in combat, special missions and/or advising/training activities in 134 countries during 2015 (Turse, 2015). These deployments involve defensive occupations, open hostilities, or secret incursions from small stations located across the world. Such quasi-legal state actions clearly are the foreign entanglements The Founders warned America to avoid.

The two trends are quite contradictory. One must ask why establishing justice, promoting general welfare, and ensuring domestic tranquility of Nixonland in 2020 requires providing for the nation's common defense with a $\$ 700$ billion budget and troops in 134 countries? Nixon's promise in 1968 to bring "Peace with Honor" in Vietnam brought about the shameful strategic defeat in 1973, 1974, 1975, following years of brutal technowar by a conscript army. After Cambodia, Laos, and Vietnam, the Pentagon ended the draft and went "professional" to recruit its servicemen and women, and then more high-tech to wage its permanent quasi-wars around the planet. Today's constitutional discourses about foreign policy and executive war powers appear to perpetuate the elaborate mystification of darker logics from Nixonland behind the bright sunny platitudes rehearsed over and over about "American Greatness" in the age of Trump. Four years after his election, Trump has weakened, mismanaged, and abused the nation's military capabilities around the world, but he has not pulled away from the material imperatives of this empire.

America's political culture, diplomatic practice, and legal constitution are at odds, and have been at least since 1890, because they mystify how the expansionist settler, military and entrepreneurial colonialism behind America's founding has continued to be perversely at work. Hence, the USA remains a nation at arms fighting countless enemies on many "new frontiers," still paying out on the promise made by JFK in his only Inaugural Address, "that we shall pay any price, bear any burden, meet any hardship, support any friend, oppose any foe, in order to assure the survival and the success of liberty" (Kennedy, 1961).

American democracy has been regarded as inseparable from liberalism (Hartz, 1955; Huntington, 1968), but this liberal culture has also proven impossible to disentangle from imperialism. The challenges of settling most of North America from 1776 to 1890 focused the energies of the original 13 independent American states (and 35 subsequent new states admitted to the Union from 1865 to 1912) in the cultural, economic, and political patterns of settler colonialism. These routines have not been left behind, or out, of everyday governance.

Manifest Destiny was the larger ethico-political design Americans regarded as a unique historic opportunity in 1789. As President Washington hinted at his first Inauguration in New York, asserting the new country "would never disregard the eternal rules of order and right, which Heaven itself has ordained. And since the preservation of the sacred fire of Liberty, and the destiny of the Republican Model of Government, are justly considered a deeply, perhaps as finally stated, on the experiment entrusted to the hands of the American people" (https//:www. archives.gov/exhibits/American_originals/inaugtx.html). Clearly, the experiment continues until today.

Ironically, a comparable world-historical opportunity was entrusted in 1989 in the hands of the American people, as "Die Mauer" was breached by East Berliners with the fragmentation of the Communist bloc, leaving the USA as the last great superpower still standing. The global hegemony the nation gained from 1898 to 1945, in fits and starts, was most militarily manifest in 1945. The job of realizing "the Republican form of government for all" has been fumbled, however, badly since George H. W. Bush's efforts to build his "New World Order" (Bacevich, 2020). 
The putatively "short-term" emergency measures to police the "air-space" of the Middle East after America's mobilization to liberate in Kuwait during 1990-1991 afforded Washington rich material opportunities for a new type of quasi-colonizing hegemony through "no-fly zones," "democratic transition planning," and "market economy building" in failed states, rogue states, transitional states and other areas of "hybrid governance," across Southwest Asia. This defense imaginary, which is sustained by the Trump White House, has grown into today's strange patchwork empire of around 800 bases today in 134 countries (Vine, 2015).

This strategic opportunity was at first not a highlight of the Clinton years, despite its Bosnian and Somalian misadventures, but the rise of the more nationalist Republican agendas in the intensely contested 1994, 1996, 1998, and 2000 elections redirected the USA by the turn of the twenty-first century toward managing its uneasy world hegemony through this "empire of bases" (Johnson, 2005). Regrettably, the resolve behind this new American militarism has drawn more from braggadocio and illusio rather blood and iron.

\section{| III. The Constitutional Crisis Already Has Happened}

In 2020, hard questions must be asked about America's political culture and legal order. Some see a constitutional crisis in the offing as the Trump White House is occupied by a tinhorn real estate mogul, who wants grandiose military parades in Washington to eclipse those of Bastille Day in Paris, a medieval-style wall running along the Mexican border from San Diego, CA to Brownsville, TX, and a new Space Force to militarize inter-planetary space. Instead of assuming that The Constitution of 1787 remains a written document still living in the hearts and minds of most American citizens, and guiding their elected officials in Washington, DC in 2020, what if something else happened?

During the Cold War America won, has it, in fact, lost its republican order to a security state, hybrid war, and global neoliberalism? And, is the full measure of today's degraded, disrupted, and dysfunctional civic condition revealed in new scripts, like the nascent, or occluded, new illiberal constitution being tweeted out daily since November 2016 by the Trump administration or Bernie Sanders' vainglorious calls for "a revolution" on his 2016 and 2020 campaign stump? Trump's two government shutdowns of 2017, 2018-2019 are not signs of "a constitutional crisis," they articulate instead the latest workings of a "Crisis Constitution" born from the Cold War and its aftermath, coming now into full bloom.

Most native-born American citizens would fail the basic United States Citizenship and Immigration Services (USCIS) civics test given to new immigrants for naturalization. They are unable to explain the Bill of Rights and its protections beyond perhaps the NRA-subsidized awareness of everyone's Second Amendment freedoms. Many citizens do not get off the sofa to vote in most elections outside of presidential contest years; even then, turnout is usually weak. Since the election of Donald J. Trump as the forty-fifth President of the United States, cable network anchors and politicos at all levels of government from both major parties fret off-the-air and in public almost $24 \times 7$ about how this or that tweet from the White House will soon trigger "a constitutional crisis." They missed the memo: the Crisis Constitution already is in force.

This crisis was triggered decades ago under "progressives," like Theodore Roosevelt and Woodrow Wilson, who embraced extra-constitutional military adventures in the Philippines and Panama as well as during World War I. With Truman, Eisenhower, LBJ, Nixon, Carter and Reagan, disregard for constitutional constraints during the Cold War, the institutional implosion 
was ready for George H. W. Bush as he and Bill Clinton failed to democratize and develop more of the former Soviet bloc. The new century -- under both George W. Bush and Barack Obama -- brought the eager imposition of ever-changing, open-ended, ad hoc writs of emergency action for military interventions and economic rescues. This pervasive "Crisis Constitution," then, has congealed more firmly from 9/11 through the Great Recession. It is hiding in plain sight in clouds of e-mails leading to bad decisions, hasty rationalizations in Oval Office addresses to the nation, and heavily redacted executive agency documents (Bacevich, 2011).

Executive branch "decision-makers" have given a more elusive direction, energy, and substance to the Crisis Constitution during this century, which operates as a thinly mystified deliberative dictatorship for executive overreach, legislative timidity, and judicial intrusion during both wartime and peacetime. Despite the new social freedom and group liberation "won in the streets by the people" from the 1960s to the 1990s, American political life since Y2K has become more unequal, illiberal, and oligarchical.

Since 1969-1970, the national budget has rarely been balanced. Moreover, new "off-budget spending" enacted the New Deal and Great Society has made a mockery of fiscal discipline by Congress and the President. Even though the twentieth century brought the costs of four wars, the Great Depression, and 1970s stagflation to the U.S. Treasury, the nation's sovereign debt was slightly less than $\$ 1$ trillion in 1980 when President Reagan was elected. It was passing $\$ 23$ trillion in February 2020 with the White House eagerly planning to add $\$ 2$ to $\$ 5$ trillion more debt by 2025 "to grow the economy" thanks to Congress rubber-stamping new tax reforms, government reorganizations, and new revenue schemes from Reagan to Trump.

The sudden eruption of the COVID-19 pandemic in March 2020, however, forced President Trump to sign an immediate $\$ 2$ trillion bailout measure in the Corona Aid, Relief, and Economic Security Act (CARES) on March 27, 2020 to prop up the US and world economies for 90 days. Already too little, too late, this emergency act surely will be only the first of many during the coronavirus pandemic of 2020 to protect key industries, shelter vital infrastructure, and maintain small businesses. While the Senate, House, and the President tussled in the ill-conceived effort to impeach and convict Trump of the abuse of power and obstruction of Congress in January and February 2020, the clear signs of this nascent pandemic were plainly evident but downplayed in the White House. In turn, the desperate struggle against this "invisible enemy" is certain to add trillions more debt in the coming months to stave off a global economic depression.

The ever-shifting ad hoc provisos of this Crisis Constitution ignore the 1787 Constitution, openly allow black budgets, accept continuing budget resolutions, and tolerate off-budget trust funds in defiance of Articles I, II, and VI to fund the government by regular legislation. Even though the USA commands, controls, and communicates endlessly the force of the world's greatest military apparatus to defend "the Homeland," the winning electorate in 2016 still felt the need to build a "huge, beautiful, and impenetrable wall” along America's southern border from the Pacific Ocean to the Gulf of Mexico. And, Mexico better pay to build this wall, because as 2019's books are closed, on February 2020 - on the eve of the 2020 stock market crash and global COVID-19 epidemic hitting the US -- the Republic's ordinary Federal debt was at least $\$ 23.4$ trillion plus with $\$ 9$ trillion more in agency debt (FHLB, GNMA, Fannie Mae, Freddie Mac, etc.).

Deficit spending is a keystone of the Crisis Constitution whose governance is sustained by well-padded military budgets, non-discretionary sustained government transfer payments to retirees, the elderly, the poor, disabled, veterans, and federal pensioners, and a commitment to backstop the U.S. dollar as the world's main reserve and exchange currency markets through the 
quasi-private Federal Reserve System. Under President Reagan, the USA made the transition from the world's largest creditor to its largest debtor nation around 1986 to sustain the emerging Crisis Constitution. It has never looked back for long, even though budget deficits were supplanted by small surpluses briefly from 1998 to 2001. Accounting for the nation's fiscal solvency at the White House and on Capitol Hill is a perpetual farce, particularly given how current Federal debt liabilities coupled with underfunded Social Security and Medicare pledges probably exceed \$6570 trillion, or slightly over three times the nation's 2019 GDP of $\$ 21$ trillion (plus or minus a few billion).

The national security state took root in 1947, the hydrogen bomb became operational in 1952, the Soviet Union began unraveling in 1964, civic order itself went into eclipse in 1968, Nixon closed the gold window at the U.S. Treasury and imposed a 10 percent tariff on imported goods in 1971, America "did not come home" in 1972 with McGovern's failed campaign against the most corrupt presidency in the USA since Harding; and "morning never really came" for most Americans in the Reagan years (Perlstein, 2015). Fears of a constitutional crisis evoked by politicos and pundits during the Trump impeachment drama were groundless because the Crisis Constitution has held sway for decades, as the Senate's cursory dismissal of the House bills of impeachment underscored in February 2020. The TV spectacle of the entire proceedings never captured the public's imagination or ire. Indeed, many voters sullenly shrugged off the outcome as almost insignificant, given how their political identities have been shaped more by the authoritarian assumptions of the Crisis Constitution rather than the fragile parchments on permanent lock-down in the National Archives on Constitution Avenue in Washington, DC. True believers in The Founders can view that 1787 document there most days if the government in not shut-down because the deliberative dictatorship of experts has entombed them in bullet-proof glass, inert gas, and bomb-proof vaults that afford a daily performance for the Crisis Constitution as a deus ex machina of America's "Charters of Freedom." Since they are not fully in force, they need to be locked down in a secure vault overnight until their viewing by tourists lest they be entirely forgotten. Too few ever learn what The Articles of the Constitution say and mean, but the spectacles of their daily unveiling fascinate visitors eager to see their tax dollars put to good work preserving spectral traces of The Constitution in this edifying fashion.

Greater domestic turmoil, economic dislocation, social immobility, and political gridlock illustrate how "the public" and "the private" spheres are different in 2020 than they were even a generation ago in 1989. The nation's routinized militarism truly now came home with the USA PATRIOT Act and its successive revisions with their open allowance of deliberative authoritarian directives being thrown wildly around at supermax prisons, border detention centers, and torn social safety nets as defense of the homeland.

\section{| IV. What Constitution?}

In the abstract, the rule of law, liberal education, economic development, and free elections have little chance for effective constitutional governance unless all eligible individual people known as "The People" practice and respect them. Likewise, this engagement must be in accord with the once more universal principles of enlightenment rationality by which this apparatus was propounded. From Russian bot farms skewing political debate on Facebook, Twitter, and YouTube to Citizens United global transnationals buying electoral influence in America, dysfunctional trends are disturbing how the USA's many peoples are "constituted" as "The People." The efforts 
in several states during the Obama and Trump administrations to reorganize voter registration practices, change identity verification, gerrymander electoral districts, and abridge suffrage rights are another set of signs underscoring how the nature and structure of the popular mandate from a sovereign people to their elected officials to uphold The Constitution actually is not being scrupulously heeded.

The 1787 Constitution once might have expressed, even for Schmitt (2008: 59), "the people's self-understanding of its political identity." Yet, who are "The People"? What is their cultural tie to such political identity? How is this link being nurtured as a civic necessity? In actuality, are certain less civic-minded people in authority now mobilizing literary tropes, cultural myths, and increasingly theological visions to generate another dangerously unstable representations of endangerment to animate the Crisis Constitution through more paternalistic, plebiscitary, and predatory powers, aiming "To Make America Great Again”? And, by the same token, why are many individuals and groups who should constitute "The People" basically supporting these efforts?

On one level of symbolic representation, the USA is still an example of a liberal constitution in action, which conforms to Schmitt's notions (2008: 59) of having a constitution in "the absolute sense" inasmuch as one can find "the concrete, collective condition of political unity and social order of a particular state." This national state formed its identity around Manifest Destiny and functioned in some mutable sense as an expansive capitalist power in accord with "its soul, its concrete life, and its individual existence" (Schmitt, 2008: 59-60) at least since its1865 refounding. With its post-bellum state-as-constitution during The Reconstruction, the USA exemplifies "an actually present condition, a status of unity and order" (Schmitt, 2008: 60).

In a second sense, this richly nuanced status of unity and order also has served since the Gilded Age as "a special type of political order" to identify and justify "supremacy and subordination" (Schmitt, 2008: 60). Its dominant forms of governance resemble Hobbes' "status mixtus," fusing Bodin's popular state (état populaire) with Aquinas' democracy (status popularis), oligarchy (status paucorum), and aristocracy (status optimatum) in ways that Polybius imagined the mixed constitution might survive almost endlessly (Schmitt, 2008: 60). Yet, it does not prevent another bolder shadow order, like the Crisis Constitution, from coexisting within its dictates to assure its own endless survival with more than legitimate popular authority.

The third articulation of constitutionality in the USA, then, is captured in Schmitt's notions about the constitution equaling "the principle of the dynamic emergence of political unity, of the process of constantly renewed formation and emergence of this unity from a fundamental or ultimately effective power and energy. The state is understood not as something existing, resting statically, but as something emerging, as something always arising anew. . out of various opposing interests, opinions, and aspirations" (Schmitt, 2008: 61) from ideologies, markets, and strategies to protect oligarchic groups at the heart of the nation's economy and society.

The scope and depth of these three emergent qualities since the Founding are anchored by the constitutional order's static characteristics, but they also express deep capacities for darker dynamic trends that are unstable, mutable or fluid: "an element of the becoming, though not actually a regulated procedure of "command" prescriptions and attributions" (Schmitt, 2008: 61). In this regard, what has been described as the "special providence" of the United States arguably has contained and channeled at least four distinct formulae, imaginaries or movements of such dynamism, which Walter Russell Mead describes as its four coexisting philosophies of "Hamiltonianism," "Wilsonianism," "Jeffersonianism," and "Jacksonianism" (Mead, 2004: 130- 
131). Their uneasy, unchecked, and unbalanced mixtures are, in part, what fuels many deformations behind this current Crisis Constitution.

Trump's disdain for the post-Cold War consensus governments of Bush (41), Clinton, Bush (43), and Obama is rooted in his supporters' ultra-nationalist suspicions about how the world's sole remaining superpower governed its affairs after the collapse of the USSR. Since the Soviet threat disappeared in 1991, failed states, displaced populations, Islamic terrorism, technological innovation, economic dislocations, and illegal migrations all beset Washington's decision-makers during the 1990s and 2000s. The White House, however, did not then put "America First." Whether under Democrats or Republicans, the "America First" agenda, as H. Ross Perot, Patrick Buchanan, Jesse Ventura, and Newt Gingrich tried to articulate it during the 1990s, was dismissed as an unworthy domestic and foreign policy.

Regrettably for some, in the vapors of victory after the Cold War, the GOP establishment and the Project for a New American Century took their evangelizing mission of military incursions for nation-building a bridge too far as they imagined a New World Order in which, as Karl Rove quipped, "we're [the USA] an empire now, and when we act, we create our own reality." This declaration implied certain "known unknowns" overseas would not constrain establishment Republicans, like Jim Baker, George W. Bush, Dick Cheney, and Donald Rumsfeld, in their failed interventions in Mesopotamia and Afghanistan. Furthermore, they also triggered the rise at the home of even more peripheral known unknowns, like Sarah Palin, Donald J. Trump, Bernie Sanders, who were and Howard Schultz ready to "swift boat" the entire Washington establishment since 1989 for its failing vision and mismanagement of the New World Order as an empire.

\section{| V. Crumbling Constitutional Order}

The architecture of the 1787 Constitution was developed to mobilize the wise checked-andbalanced designs for a separation of powers, as affirmed by Polybius, Machiavelli, Pufendorf, and Montesquieu. By creating institutional counter-weights against the overweening executive, legislative or judicial authority at the federal level as well as within each independent state in the federation, continuity, and conflict-management were maximized. Staggered terms for the executive and legislative authorities, along with open appointments to the judiciary, made factions more difficult to form and then thrive, even though political parties quickly emerged to serve as policy proponents, sectional coalitions, or class advocates. From 1776 to 1861, the American state was largely limited in power, and minimalist in its operation, leaving most governance to the states and counties.

The government plainly supported economic development and territorial expansion, but the engrained order of liberalism in civil society and markets gave local/regional authorities considerable latitude. The struggles over slave or free labor, territorial settlement, domestic manufacture or foreign imports, bank oversight, and monetary policy challenged all levels of government as the Union grew from 13 states to 33 from the 1780 s to the 1850 s. The outbreak of the Civil War forced the federal government to rethink its role in many dimensions of everyday public life to defeat the secessionist Confederate States of America in war, rebuild their governments under military occupation during Reconstruction, cope with the growth of new industries, and pacify the Trans-Mississippian West to admit another 15 of the lower 48 states into the Union from 1860 to 1912.

During the decades spanning the years until the end of World War II, elite managerialists 
and bureaucratic mechanisms needed to operate a more capacious state apparatus gradually were constructed in a manner that pitted the urban and industrial cultures of the Gilded Age and Progressive Eras against the more rural and agricultural cultures of the Founders. By 1883, the Pendleton Act specified how such expert personnel at work at the Federal level would operate. As Michaels notes, "this legislation laid the groundwork for an independent, professional civil service capable of playing a central, rivalrous, and durable role in modern administrative governance" (2017: 70).

In the aftermath of the twentieth century's many bureaucratic exertions to fight World War I and II, control immigration more actively after the 1920s, organize a national income tax, establish a centralized quasi-statal monetary system, manage the economic recovery from the Great Depression, and respond to new geostrategic obligations after V-J Day, Congress essentially ratified the existence of a more powerful "service state" due to its indispensable engagement in everyday life with the Administrative Procedure Act (APA) of 1946.

As Justice Antonin Scalia observed, the APA became, like the Pendleton Act, a political gamechanger inasmuch as it unfolded as a "superstatute" (Scalia, 1979: 346) that, in effect, materially supplemented The Constitution. With the acceptance of the Supreme Court and Attorney General, the Administrative Procedure Act evolved tacitly as a codicil to The Constitution by organizing, standardizing, and rationalizing agency regulations and rulings from within Washington itself by giving a Crisis Constitution room to operate. In the shaping of the rising security state, then, the APA opened new ranges of sovereign power to the degree that "rules are generally applicable statement of agency policy that have the force of law. They are, in appearance and effect, agencymade laws" (Michaels, 2017: 46), but their scope and impact are like The U.S. Constitution.

As Eskridge and Ferejohn assert, these superstatutes accord close to constitutional significance to certain new legislative actions, which transform the private and public understandings of legality, governance and order after considerable bipartisan debate and acceptance intergenerationally to accept as "normal." Certain aspects of this shift, once admired and accepted by many Democrats and Republicans alike, were President Nixon's Tory environmentalism and New Economic Policy in the 1970s (Eskridge and Ferejohn, 2010: 6-26). The textualist and originalist readings of the 1787 Constitution to oppose the Crisis Constitution's expansion of superstatute authority were articulated by the Rehnquist court after 1986, but this ideological outlook gained only some traction with the appointment of Justices Scalia, Thomas, Gorsuch, and Kavanaugh after 1988. Ironically, such originalist readers of The Constitution maintain illusions of continuity, while they endorse flexible initiatives to introduce new discontinuities.

Such ad hoc improvisations over many years across a wide spectrum of administrative agencies cannot be ignored. With the National Security Act (1947) creating the Defense Department and Central Intelligence Agency under President Truman, The Great Society legislative acts under President Johnson, and then successive rounds of new environmental, privacy, war-making, and workplace legislative actions during the Nixon, Ford, and Carter administrations, like the National Emergency Act of 1976, the APA comes into its own as an "organizing charter for the administrative state" (Sunstein and Vermeule, 46).

The USA PATRIOT Act of 2001 expressed another superstatute with its multi-pronged measures for enhancing border security, intensifying government surveillance powers, moneylaundering countermeasures, loosening of legalimpediments in terrorism investigations, supporting victims of terrorism, increasing shared information in critical infrastructure operation, hardening criminal procedures in terrorism cases, and enhancing intelligence community capabilities. Due 
to its complex and comprehensive intrusions on ordinary civic freedoms, sunset provisions were embedded in the legislation, and modifications of several sections were made during the Bush (43) and Obama presidencies. Nonetheless, these legislative innovations were only refined and then basically rebranded in the USA FREEDOM Act of 2015 by President Obama.

Along with the Homeland Security Act of 2002 establishing the Department of Homeland Security with its realignments of multiple cabinet-level sub-agencies, intelligence community operations, and border security agencies, the immediate response to the "global war on terror" radically reconfigured the workings of the national security apparatus as well as imposed many new intrusive legislative measures on citizens and non-citizens alike with little congressional foresight, consideration or review under the Crisis Constitution. To have a permanent Homeland Security agency tacitly underscores how widely Washington's increasingly illiberal empire is mobilizing so many forces of homeland insecuritization against its global dominion over energy resources, high finance, world trade, and advanced technology (Hardt and Negri, 2000; and, Gonzales, 2018).

At the same time, however, the routine intelligence work of national security agencies tied to the Departments of Defense or Homeland Security has deflected attention from the CIA's more intrusive and sometimes effective covert interventions -- violent and nonviolent -- abroad. Those activities by such clandestine force are cynical but rational, not so much because it prevents the nation's adversaries from knowing what Washington decision-makers are doing but rather "to protect themselves from congressional scrutiny or from political bureaucratic rivals elsewhere within government" (Johnson, 2005: 10). Behind the veils of bureaucratic secrecy, one senses how the nation's institutional centers of gravity have shifted toward bellicose policy choices (Bacevich, 2013).

Largely unchecked executive actions are "an integral part of American militarism and the secrecy that accompanies it" (Johnson, 2005: 11). After Washington continued seeking the nation's Manifest Destiny for over a century by demanding exclusive sovereign power over as well as the territories of weaker powers (Hawaii, Columbia, Spain, Nicaragua, Japan, Iraq, Syria, Libya, etc.) via overt interventions, covert actions or open war (Johnson, 2008; Kinzer, 2007). Their larger logic evinces itself beyond the USA in the bases established by the War and Navy Departments in Guantanamo Bay, Pearl Harbor, Subic Bay, Alaska, Panama, Guam, the Marianas, Midway Island, before 1941 in "the empire of military bases" that sprang "up more or less undetected and that is today a geopolitical fact of life" (Johnson, 2005: 11).

These global networks of military installations today still constitute the operational foundation for what Bacevich (2011: 14) labels "the sacred trinity" of American geopolitics:

An abiding conviction that the minimum essentials of international peace and order require the United

States to maintain a global military presence, to configure its forces for global power projection, and to count for existing, or anticipated threats by relying on a policy of global interventionism (2011: 14).

In keeping with the Crisis Constitution politicians, statesmen, and thinkers, this triad of strategic services came to assure "The Project for The New American Century" organized around alliances and interests favorted by its neo-conservative leadership (Johnson, 2008). Their imperious aspirations, in turn, indeed became "the American credo," summoning "The United States--and the United States alone--to lead, save, liberate, and ultimately transform the world" (Bacevich, 2011: 12).

One can map the degradation of democracy in the concretization of an ethos, which emerged from the apparatuses and practices of the empire of bases, as it swung into action from the 
"Vietnamization" of the failed Vietnamese war at the origins of Nixonland. Hence, one finds with Nixon and Kissinger through the decades to Trump and Pompeo, a strategy for "relating to contemporary reality; a voluntary choice made by certain people; in the end, a way of thinking and feeling; a way, too, of acting and behaving that at one and the same time marks a relation of belonging and presents itself as a task" (Foucault: 1984: 39) for "a democratic empire" to tackle under the banners of "The Project for the New American Century" or "America First," whatever it takes to "Make America Great Again," like Trump's and Pompeo's program for the "Afghanization" of the failed war in Afghanistan against the Taliban since 2001.

Such fluid dynamics of authority pretend to challenge the passions of popular government; but, in actuality, they favor more managerialist discursive devices where flexible visions of "truth," or "a system of ordered procedures for the production, regulation, distribution, circulation, and operation of statements" (Foucault, 1980: 133) by experts can dissipate the ardor of popular solidarity. In the arid deliberations of America's guardians of global order, trust is granted to power/knowledge formations largely generated of, for, and by the professional-technical elites and their meritocratic oligarchy, who run the empire like "government contractors." Here, the Tenth Amendment to the 1787 Constitution, namely, that "The powers not delegated to the United States by the Constitution, nor prohibited by it to the states, are reserved to the states respectively, or to the people" is turned on its head. The states typically appeal to Washington, DC for help, allowing federal agencies to do their work. In turn, the people's reserve powers are lost in panic, incapacity or confusion, which pushes them as democratic subjects to consign their sovereign power over to "the elites" and "the experts" to gain security over keeping freedom. Citizens, then, let those "who know best" decide, trust "the private sector" with its own capital, ideology, and technology, and then wait for policy process outcomes to maintain their collective stability, security, and sustainability.

\section{| VI. Conclusion: Democracy as Disorder}

Exploring the unwritten rules of the Crisis Constitution, as this analysis asserts, is crucial. As America's contemporary scripts for governance, they uneasily co-exist with foundational principles of The Constitution in Trump's presidency. Working from within his own small spheres of relative insignificance grounded in reality television, real estate, and raw egoism, Trump appears unwittingly to be tripping across the philosophical trails to "a state of emergency" blazed by Carl Schmitt as he has sewn disorder since 2016. The first American death of COVID-19 happened February 29, 2020 in Washington state. On March 1, the USA was booming atop an 11 year-run of economic expansion with unemployment at a 50 year low of 3.5 percent, and Dow Jones Industrial Average close to an all-time high of 30,000. By March 31, 2020, COVID-19 deaths in the USA were over 6,000 with over 250,000 known cases of illness. In one month, 10 million people lost their jobs, the Dow Jones Industrial Average fell to 21,917, many businesses were shut, many airlines are fearing bankruptcy, and the end of this catastrophic event could not be accurately predicted -- many more weeks, a few months, perhaps a year are all plausible durations (Wall Street Journal, 2020). Strangely, however, as a would-be authoritarian strongman, Trump has let this crisis go to waste for him politically.

Despite of his pious pronouncements to the mass media about his ability to discharge the duties of his office faithfully as one of America's best presidents, Trump has proven himself to be ineffectual: the Herbert Hoover of the twenty-first century. Even worse, he questions, if 
not repudiates, key elements of the universal secular rationality animating America's embedded political liberalism (Rawls, 2005), including its civic secularism, the rule of law, a free press, the primacy of rational deliberative discourse over irrational executive will, strong constitutional government, the legitimacy of scientific-technical expertise, and a contractarian vision of limited state power in civil society.

Madison accepted the reality of factions, conflicting interests, and endless maneuvering for greater advantage by all against others to create legislative outcomes because in the nation's political deliberations and debates key actors could hash out results, by and large, through reasoned arguments in accord with common cultural conventions. Even Schmitt recognized governance through democratic discussion springs from "shared convictions as premises, the willingness to be persuaded, independence of party ties, freedom from selfish interests" (Schmitt, 1988: 5). Many regard such disinterest as implausible, but these qualities "still officially belong to parliamentary constitutions, make quite clear that all specifically parliamentary arrangements are this particular concept of discussion" (Schmitt, 1988: 5). Trump, however, flouts these bare minimum standards of civic deportment with his dismissive nick-names, Twitter rants, incessant insults, and mistrust of seasoned public servants in a manner that reeks "this is not normal" with posturing self-centered bluster (Woodward, 2018).

Trump's presumptuous campaigning for re-election in 2020 since his 2016 victory also displays a deep disrespect for most regular parliamentary democratic precepts. During his first three years in office as President of the United States (POTUS), Trump has violated them on a daily basis, which culminated in the House vote to impeach him on two counts of the abuse of power -- enlisting foreign agents to aid his 2020 re-election campaign and obstructing Congress, before Christmas 2019. As David Axelrod, an Obama adviser, notes, "one way he's changed the institution is that most presidents see themselves as trustees of democracy. And where every president is irritated by the limitations of democracy on them, they all grudgingly accept it. He has not. He has waged war on the institutions of democracy from the beginning" (Baker, 2017: A1). His partisan efforts to delay the House impeachment investigation, and rig the Senate trial on impeachment during 2019 and 2020 to exonerate him as POTUS 45, simply underscore this cynicism.

The embedded wisdom of "the culture of a liberal society in America," as Hartz (1955, 3-34) defines it, and the separation and division of power at the core of the "Tudor polity" at the heart of American constitutionalism (Huntington, 1968: 93-139), and the cultural pay-off from "the last capitalist revolution" (Moore, 1967: 111-158), are institutional legacies that have anchored governance in the USA for centuries. Trump's ignorance of and/or contempt for these institutional practices and structures are another sign of his unawareness of the presidency as an institution.

Yet, his divisive political attacks have been tolerated for years by the larger Republican Party in its efforts to win the White House, which are more troubling. Trump incarnates this larger shift of most GOP partisans to regain, and then stay, in control at any cost since the Tea Party rebellion of 2009-2010, which many Republicans used to nurture dangerous antiliberal propensities among their constituents. That the extremely polarized 2016 electorate -- by a narrow margin in the Electoral College -- chose Trump over Hilary Clinton says something disturbing about "the incumbent GOP elites" as well as "the voters" in Nixonland today. The 1787 Constitution has firewalls against demagoguery and autocracy. Unfortunately, the Crisis Constitution -- in the hands of the wrong executive and corrupt partisans -- can be worked around in a manner that all 
but eliminates almost all checks-and-balances through autocratic bullying, legislative slowdowns or dismissive neglect.

Arguably, the normalization of a permanent state of emergency at the core of the Crisis Constitution first became ordinary during the Truman administration, given Truman's unexpected inauguration in 1945 and activist use of executive power to end World War II, shift to a peacetime economy, deal with the onset of the Cold War, and foster a North Atlantic coalition to resist the USSR in Europe and Asia. Even though Congress passed, albeit with little effect, the National Emergencies Act of 1976 to limit how often and extensively these events might be evoked after Vietnam, the Crisis Constitution remains well-adapted to appeal to national emergency edicts and executive cultural imaginaries. Much of "the politics presidents make" (Skowronek, 1996) that Truman, Eisenhower, Kennedy, and Johnson evoked during the darkest days of the Cold War comes from such "states of exception." Since 1968, the citizens of Nixonland almost need to hear these rallying cries in elections -- from Peace with Honor, a War on Drugs, Whip Inflation Now, Thermostat Control as Geopolitics, Star Wars (Anti-Missile Defense) plus Tear Down this Wall, a Thousand Points of Light, The Man from Hope, the New American Century, or Make America Great Again -- that echo through the decades from Nixon to Trump.

The patchy rules and regulations of anti-communism during the Cold War have been reformatted since 2001 in new "superstatutes," like the USA PATRIOT and USA FREEDOM Acts, putting the USA into new modes of permanent mobilization against unclear enemies for an uncertain length of time with an unending timeline subject to perfunctory periodic reauthorizations. To believe such extreme government actions were the most rational choices by informed strategic experts or the uncontested will of the people is gravely mistaken. Instead, the panic of 2001 allowed the broader American public to be "won over through an appeal to a propaganda apparatus whose maximum effect relies on and appeals to immediate interests and passions. The argument in a real sense that is characteristic for genuine discussion ceases . .. one may, therefore, assume as well known today that it is no longer a question of persuading one's opponent of the truth or justice of an opinion but rather of winning a majority in order to govern with it" (Schmitt, 1988: 7). Whether it is sleeper cells of ISIS terrorists or "the invisible enemy" of COVID-19, fake news, post-truth, and endless disinformation at the core of the Crisis Constitution enables inept chief executives, like Presidents Trump, to toss aside established policies and practices win the support of voters through panic and then rule through it (Landle, 2017: A1).

The deepest foundations for liberal order in the modern era once rested upon rational calculation by individuals to choose strict order over anarchic chaos in their everyday collective life. Left to their own devices, as Madison presumed, free rational agents always would push their own selfish agendas, disagree over how to manage collective goods, and disregard prior agreements when it suits their current aspirations. In the resulting chaos, basic social order would not shred into the tangled threads of a truly debased social order in which, as Hobbes would note, reason is ignored, authority is disdained, and freedom is abused.

In many respects, the U.S. Congress, like parliaments across post-WWI Europe Schmitt criticized, "itself appears a gigantic antechamber in front of the bureaus or committees of invisible rulers" (Schmitt, 1988: 7). Today in the USA, both national political parties are inclined to serve shifting oligarchic elite interests, and the courts openly to favor corporate private property agendas is dangerous, because the oligarchs behind them ignore "the interests of the poor, consumers of dangerous food and drugs, the elderly, traders on security markets and victims of unfair trade 
practices" (Sunstein, 1987: 438). Unless they are eclipsed by a string of Trump's impetuous Tweets, surviving centers of technical expertise, administrative acumen, and bureaucratic judgment now fill the empty spaces of popular democratic deliberation in the nation's current crises, because citizens fail to act directly in their own constitutional interests (Orren and Skowronek, 2017; Kettl, 2009; and, Patterson, 2000).

The Trump administration's efforts to defy existing laws, degrade education, distort economic development, and diminish free elections illustrate how fully the nature and structure of the Crisis Constitution are accepted as normal practices in the nation's daily routines. In actuality, key people in authority, like Vice President Pence, White House official Stephen Miller, Secretary of Commerce Wilbur Ross or Counselor to the President Kellyanne Conway are mobilizing cultural myths, and increasingly theological visions, to bolster retrograde nationalist logics to animate Trump's presidential program now "To Keep America Great." Yet, their most favored agents for advancing this agenda appear to be no longer appear to be "We, the People" but rather "We, the Corporations," which have enjoyed the new conditions of governance created around "the powers of freedom" (Rose, 1999) for business to get more tax cuts, market protection, and regulatory relief. The freedom to exercise this power, in turn, has recast the USA's industrial democracy with new characteristics that marginalize the majority of people who once constituted "The People" by reimagining corporations as persons, money as speech, wealth as rights, ideology as image, parties as syndicates, and government as spectacle.

To conclude, this analysis of America in "The Trump Zone" returned to Nixonland at its points of emergence during 1968-1974. It tracked how deformed notions of order came to build a different imperfect union with another sort of justice, an oppressive domestic tranquility, an unbridled approach to defense, a lessened general welfare, and an unequal blessing of liberty over five decades. To deliver on his promises to posterity, the White House under Trump essentially has tried to trigger, like Nixon after 1968, a reawakening in the United States of America to become "Great Again" when it ironically was, in so many ways already regarded as great. Regrettably and remarkably, it continues to fail, as the challenges of "the 50-state disaster" emerging from the COVID-19 pandemic of 2020, and the feckless orders to the public "to shelter in place" amid a frozen global economy, still have not forced President Trump, and the few experts he has still working with him, actually to "do the right thing" after they have tried everything else to downplay, ignore or mismanage this devastating public health and national economic crisis.

* A draft of the paper initially was presented at 2nd Biennial Conference of the Caucus for a New Political Science, Isla Grand Beach Resort, South Padre Island, Texas, February 24-26, 2019 


\section{References}

Bacevich, Andrew J. 2020. The Age of Illusions: How Americans Squandered Its Cold War Victory. New York: Metropolitan Books.

Bacevich, Andrew J. 2013. The New American Militarism: How Americans are Seduced by War, second updated edition. New York: Oxford University Press.

Bacevich, Andrew J. 2011. Washington Rules: America's Path to Permanent War. New York: Metropolitan Press.

Baker, Peter. 2017. "For Trump, A Year of Reinventing the Presidency," New York Times (December 31), A1.

Dean, Mitchell M. 1999. Government: Power and Rule in Modern Society. London: Sage.

Eskridge, William N. and John Ferejohn. 2010. A Republic of Statutes: The New American Constitution. New Haven: Yale University Press.

Foucault, Michel. 1984. The Foucault Reader, ed. Paul Rabinow. New York: Vintage.

Foucault, Michel. 1980. Power/Knowledge: Selected Interviews \& Other Writings, 1972-1977. New York: Vintage.

Goldwater, Barry. 1964. “Goldwater's 1964 Acceptance Speech," The Washington Post.com. [https://www. washingtonpost.com/wp-srv/politics/daily/may98/ goldwaterspeech.htm]

Gonzalez, George A. 2018. Energy, the Modern State, and the American World System. Albany, NY: State University of New York Press.

Hardt, Michael and Antonio Negri. 2000. Empire. Cambridge, MA: Harvard University Press.

Hartz, Louis. 1955. The Liberal Tradition in America: An Interpretation of American Political Thought. New York: Harcourt Brace.

Huntington, Samuel. 1968. Political Order in Changing Societies. New Haven: Yale University Press.

Johnson, Chalmers. 2010. Dismantling the Empire: America's Last Best Hope. New York: Metropolitan Books.

Johnson, Chalmers. 2008. Nemesis: The Last Days of the American Republic. New York: Metropolitan Books.

Johnson, Chalmers. 2005. The Sorrows of Empire Militarism, Secrecy, and the End of the Republic. New York: Metropolitan Books.
Kennedy, John F. 1961. "Inaugural Address of John F. Kennedy," The Avalon Project, (January 20). See: http://avalon.law.yale.edu/20th_century/kennedy.asp

Kettl, Donald F. 2009. The Next Government of the United States. New York: W.W. Norton.

Kinzer, Stephen. 2007. Overthrow: America' Century of Regime Change from Hawaii to Iraq. New York: Times Books.

Landle, Mark. 2017. "Trump, the Insurgent, Breaks with 70 Years of American Foreign Policy," New York Times (December 29), A1.

Lowi, Theodore J. 1979. The End of Liberalism: The Second Republic of the United States. New York: W. W. Norton.

Luke, Timothy W. 2016. "The Dissipation of Democracy in 2016: On the Emptiness of Elitism and the Poverty of Realism in the Trump Zone." Fast Capitalism (August), [http://www.fastcapitalism.com].

Mead, Walter Russell. 2004. Special Providence: American Foreign Policy and How it Changed the World. New York: Knopf.

Michaels, Jon D. 2017. Constitutional Coup: Privatization's Threat to the American Republic. Cambridge, MA: Harvard University Press.

Moore, Barrington, Jr. 1967. Social Origins of Dictatorship and Democracy: Lord and Peasant in the Making of the Modern World. Boston: Beacon Press.

Nixon, Richard M. 1969. "First Inaugural Address of Richard Milhous Nixon," The Avalon Project, January 20). See: [http://avalon.law.yale.edu/20th_century/ nixon1.asp]

Orren, Karen and Stephen Skowronek. 2017. The Policy State: An American Predicament. Cambridge, MA: Harvard University Press.

Patterson, James T. 2000. America's Struggle against Poverty in the Twentieth Century. Cambridge, MA: Harvard University Press.

Perlstein, Neil. 2015. The Invisible Bridge: The Fall of Nixon and the Rise of Reagan. New York: Simon \& Schuster.

Perlstein, Neil. 2008. Nixonland: The Rise of a President and the Fracturing of America. New York: Scribner.

Perlstein, Neil. 2001. Before the Storm: Barry Goldwater and the Unmaking of the American Consensus. New York: Hill and Wang. 
Rawls, John. 2005. Political Liberalism. (Columbia Classics in Philosophy) Expanded Edition. New York: Columbia University Press.

Rose, Nikolas. 1999. Powers of Freedom: Reframing Political Thought. Cambridge: Cambridge University Press.

Scalia, Antonin. 1979. "Vermont Yankee, the APA, the D.C. Circuit, and the Supreme Court," Supreme Court Review, Vol. 1978: 346-409.

Schmitt, Carl. 2008. Constitutional Theory. Durham: Duke University Press.

Schmitt, Carl. 2004. Legality and Legitimacy. Durham: Duke University Press.

Schmitt, Carl. 1988. The Crisis of Parliamentary Democracy. Cambridge, MA: MIT Press.

Skowronek, Stephen. 1997. The Politics Presidents Make. Cambridge, MA: Belknap Press.

Skowronek, Stephen. 1982. Building a New Administrative State: The Expansion of National Administrative Capacities, 1877-1920. New York: Cambridge University Press.

Sunstein, Cass R. 1987. "Constitutionalism After the New Deal 101,” Harvard Law Review 421 (1987), 421-438.

Sunstein, Cass and Adrian Vermeule. 2015. "Libertarian Administrative Law," University of Chicago Law Review, Vol. 82, no. 1: 393-473.

Trump, Donald J. 2017. "The Inaugural Address," WhiteHouse.gov. (January 20). [https:/ /www.whitehouse. gov/briefings-statements/the-inaugural-address/].

Turse, Nick. 2015. "How Many Wars Is the US Really Fighting?, The Nation (September 26). See: [https://www.thenation.com/article/ how-many-wars-is-the-us-really-fighting/]

Vine, David. 2015. "Where in the World is the U.S. Military?," Politico Magazine (July/August). See [https://www.politico.com/magazine/story/2015/06/ us-military-bases-around-the-world-119321]

Wall Street Journal. 2020. "The Month That Changed Everything," (April 4): B1, B6-9.

Washington, George (with James Madison, 1792, and Alexander Hamilton, 1796). 1796. “The Address of General Washington to the People of the United States on his declining of the Presidency of the United States," American Daily Advertiser (September 21). [www.presidency.ucsb.edu/ws/index.php.pid=65539].

Woodward, Bob. 2018. Fear: Trump in the White House. New York: Simon \& Schuster. 
